\title{
Redevelopment of Tissue Proliferation Symptoms in Rooted Rhododendron Cuttings
}

\author{
Mark H. Brand \\ Department of Plant Science, U-67, University of Connecticut, Storrs, \\ CT 06269-4067
}

\section{Richard Kiyomoto \\ Department of Forestry and Horticulture, The Connecticut Agricultural Experiment Station, New Haven, CT 06504-1106}

Additional index words. epigenetic, micropropagation, propagation, tumor

\begin{abstract}
Tissue proliferation (TP) of Rhododendron sp. is characterized by basal tumors that often develop into numerous dwarf shoots. Growers need to know if the TP condition will recur in plants grown from normal-appearing cuttings collected from plants with TP tumors. Stem cuttings of seven cultivars were collected from stock plants with TP $[$ TP(+)] and without TP $[$ TP(-)] and rooted. Plants were grown in containers outdoors for 2 years and were then evaluated for tumor formation and other TP-related morphological symptoms. Shoots of TP(+) plants were either similar in length to shoots of TP(-) plants, or were shorter, as was the case for 'Boule de Neige', 'Catawbiense Album', and 'Montego'. Plants grown from TP(+) cuttings of all cultivars had more leaves per growth flush than did plants grown from TP(-) cuttings. 'Holden', 'Montego', and 'Scintillation' $\mathbf{T P}(+)$ leaves were narrower than leaves from $\mathbf{T P}(-)$ shoots and had greater length : width ratios. Leaves of TP(+) 'Montego' and 'Scintillation' plants were shorter and smaller than leaves from their TP(-) counterparts. Tumors were not observed on any propagated plants, regardless of the TP status of cutting stock plants. To further test the influence of age and TP status of source plants used for cutting propagation, 'Montego' plants were grown from cuttings collected from the following sources: 1) in vitro shoot cultures; 2 ) 3year-old plants with TP; 3) 6-year-old plants with TP; and 4) TP(-) plants. Cuttings from TP(+) micropropagated plants less than 3 years old were more likely to develop tumors than were cuttings from older plants. Eighty-three percent of plants from microcuttings and $74 \%$ of plants from cuttings of 3-year-old $\mathbf{T P}(+)$ plants formed tumors, whereas no plants grown from 6-year-old TP(+) or TP(-) cuttings did so. Large tumors that surrounded half or more of the stem were more likely to develop on plants grown from microcuttings than on plants grown from the next youngest, 3-year-old TP(+), stock plants. Growers must be aware that cuttings from $\mathbf{T P}(+)$ plants may produce plants that exhibit morphological and growth abnormalities, possibly even including tumor redevelopment.
\end{abstract}

Tissue proliferation (TP) is a disorder in which abnormal callus-like growths, or tumors, are produced at or near the crown or base of a woody plant (LaMondia et al., 1992). A proliferation of short shoots or buds may form on tumors of certain cultivars (Brand and Kiyomoto, 1992). In addition to tumors and tumor-associated shoot proliferation, Brand and Kiyomoto (1997) observed specific shoot morphological differences between Rhododendron 'Montego' plants with and without TP tumors. Genera in which TP has been observed include Rhododendron, Kalmia, and Pieris (Linderman, 1993), but TP has been

\footnotetext{
Received for publication 5 Oct. 1998. Accepted for publication 5 Jan. 1999. Storrs Agricultural Experiment Station scientific contribution 1834. This work was supported in part by funds made available through the Holden Arboretum, Mentor, Ohio, and the Connecticut Chapter of the American Rhododendron Society. The cost of publishing this paper was defrayed in part by the payment of page charges. Under postal regulations, this paper therefore must be hereby marked advertisement solely to indicate this fact.
}

most prevalent in Rhododendron. Within the genus Rhododendron, genotype has a significant effect on TP incidence and severity (McCulloch and Britt, 1997). At least 40 Rhododendron cultivars with TP have been observed (Zimmerman, 1997).

Although TP appears to be similar to crown gall, previous experimental evidence suggests that TP does not result from Agrobacterium tumefaciens infection (Zimmerman, 1997). The morphology of TP also appears to be similar to that of lignotubers, which are woody outgrowths at the stem base that contain numerous dormant buds (Del Tredici, 1992). However, TP tumors do not generally exhibit normal lignotuber characteristics (Brand and Kiyomoto, 1994; Del Tredici, 1992; Mercure et al., 1998). The most widely accepted theory is that TP results from epigenetic changes that are induced by the tissue culture process (Brand and Kiyomoto, 1997; Linderman, 1993). Specifically, Brand and Kiyomoto (1997) found that TP-like symptoms in Rhododendron 'Montego' were associated with adventitious shoot formation in vitro.
Almost all instances of TP can be traced back to propagation by tissue culture (Linderman, 1993; Zimmerman, 1997). From nursery surveys, Mudge et al. (1997) determined that TP symptoms developed only on plants that had been propagated by stem cuttings collected from previously micropropagated plants. Growers generally use their existing container stock as the source of cuttings for next year's Rhododendron crop. Of particular importance to this practice is whether normal-appearing cuttings taken from the tops of plants with TP will produce plants that ultimately develop the TP disorder. Since TP often is not noticeable until a plant is 2 or 3 years old, time and crop losses to growers would be large if TP were transmitted to a new crop by cutting propagation. The objectives of this study were to determine 1) if TP is transmitted to plants through cutting propagation, and 2) if stock plant age from micropropagation affects the incidence and severity of TP symptoms in plants propagated from cuttings.

\section{Materials and Methods}

Propagation and plant maintenance. Terminal cuttings were collected and stuck to root in late November. Floral buds were removed when present and cuttings were trimmed at the base to a maximum stem length of $10 \mathrm{~cm}$. Leaves were trimmed to remove the distal one-third of the blade. All cuttings were wounded $(1 \mathrm{~cm}$ basal wound on two sides of the stem) and were dipped in Hormex, rooting powder No. 16 (1.6\% indole-3-butyric acid) (Brooker Chemical, North Hollywood, Calif.). Cuttings were stuck in $35 \times 50 \times 9$-cm black plastic flats filled with 1 sphagnum peat : 1 coarse perlite $(\mathrm{v} / \mathrm{v})$. Each flat contained 30 cuttings spaced evenly in six rows of five. Sixty cuttings were stuck for each cultivar $x$ TP status combination. Cuttings were rooted using bottom heat and intermittent mist (electronic leaf-controlled) in the greenhouse for $120 \mathrm{~d}$ at $21{ }^{\circ} \mathrm{C}$ day $/ 17^{\circ} \mathrm{C}$ night. Following rooting, cuttings were acclimated for $45 \mathrm{~d}$ in a greenhouse with $30 \%$ shade provided by black polypropylene cloth. Microcuttings were also harvested in late November and were rooted in 1 sphagnum peat: 1 fine perlite $(\mathrm{v} / \mathrm{v})$ in plastic, clear-lidded humidity chambers. Microcuttings received no wounding or auxin treatment.

Rooted cuttings were potted in 3 pine bark : 2 sphagnum peat : 1 sand (by volume) amended with ground dolomitic limestone and gypsum, both at $3.6 \mathrm{~kg} \cdot \mathrm{m}^{-3}$. During the first growing season, cuttings were grown in $2.6-\mathrm{L}$ containers (Classic 300S; Nursery Supplies, Fairless Hills, Pa.); in mid-May of the second season they were repotted into 6.1-L containers (Classic 600; Nursery Supplies). All plants were topdressed with Sierrablen $17 \mathrm{~N}-2.6 \mathrm{P}-$ 8.3K 8- to 9-month formulation (The Scotts Co., Marietta, Ga.) using $10 \mathrm{~g}$ per pot following transplanting the first season, and $50 \mathrm{~g}$ per pot the second year. During the period from 15 May to 31 Oct. (growing season), 2.6-L containers received $\approx 1.5 \mathrm{~L}$ of water every other day and 6.1-L containers received $4 \mathrm{~L}$ of water every other day. Irrigation was provided through trickle emitters using an automated 
controller. During the growing season, plants were placed on a gravel-covered growing area in full sunlight. Between growing seasons (1 Nov. through 14 May), plants were overwintered in an unheated white polyethylene-covered hoop house and hand watered as needed. At the conclusion of the overwintering period, plants were pruned according to standard nursery practices by removing much of the last growth flush and further shaping the plants as needed. Plants received no pesticide or herbicide treatments to avoid any effect these products might have on the induction of TP symptoms. Hand weeding was done as needed.

Plant growth, shoot, and foliar measurements. Plant size was calculated as the product of two plant widths, taken at right angles to each other, and plant height. A vigorous shoot on each selected plant was chosen for measurement, avoiding shoots with a late-season growth flush. Basal shoot length was measured from the bud scale scars to the first leaf, and total shoot length from the bud scale scars to the base of the terminal bud. The number of leaves per shoot (growth flush) was also counted. Leaf measurements were taken on the first five fully expanded apical leaves on each selected shoot. Leaf length was measured from the tip of the blade to the blade base and leaf width at the widest part of the blade. Leaf area was obtained using a LI 3100 leaf area meter (LI-COR, Lincoln, Nebr.).

TP symptom development in plants grown from $T P(+)$ and TP(-) cuttings. The following seven Rhododendron cultivars were used in the study: 'Besse Howells', 'Boule de Neige', 'Calsap', 'Catawbiense Album', 'Holden', 'Montego', and 'Scintillation'. Plants identified as TP(-) had no TP symptoms and were known to have been propagated by a vegetative method other than tissue culture, or were the original seedling plant named as the cultivar. Plants with a history of tissue culture were excluded from consideration as TP(-), even if they were free of TP symptoms, because of the role tissue culture may play in the induction of TP. Stock plants selected as TP(+) were those with TP symptoms evident at the time the cuttings were collected.

$\mathrm{TP}(-)$ cuttings were collected from single large plants, typically 20 to 30 years old. TP(+) cuttings were collected from 4- to 6-year-old container-grown plants. Because TP is a relatively new occurrence, large, well-established $\mathrm{TP}(+)$ plants, with backgrounds comparable to the TP(-) stock plants, were not available. Because many $\mathrm{TP}(+)$ plants were needed to supply enough cuttings for the study, cuttings were rooted and 25 rooted cuttings were randomly selected for each cultivar $\times$ TP status combination and grown for 2 years.

Plants were analyzed at the end of the second growing season to avoid any confounding carryover effects resulting from possible disparity in plant vigor between $\mathrm{TP}(-)$ and TP $(+)$ stock plants. Data were collected on all plants for tumor incidence, plant survival, and plant growth. In addition, 10 plants of each cultivar $\times$ TP status combination were selected randomly and measured for shoot and foliar characteristics.
Influence of $T P(+)$ plant age following micropropagation on TP symptom development in rooted cuttings. Rhododendron 'Montego' cuttings were collected from TP(-) plants and from $\mathrm{TP}(+)$ plants of three ages from tissue culture: 6 year old, 3 year old, and microcuttings. Three-year-old $\mathrm{TP}(+)$ stock plants were rooted as microcuttings in early spring and were then grown in a greenhouse for 1 year, followed by 2 years in outdoor transplant beds. Six-year-old TP(+) plants were grown as described for 3-year-old plants, with an additional 3 years of growth in field areas. Cuttings from 3- and 6-year-old TP(+) plants were collected only from plants with obvious TP tumors. Microcuttings were harvested from shoot cultures with a history of producing plants with TP symptoms. Cultures were maintained on woody plant medium (Lloyd and McCown, 1980) containing $10 \mathrm{~mm}$ 6-(g,gdimethylallylamino)purine, $3 \%$ sucrose, $0.3 \%$ agar, and $0.1 \%$ Phytagel (Sigma Chemical Co., St. Louis), with a $\mathrm{pH}$ of 5.2 prior to autoclaving. Shoots were grown on $30 \mathrm{~mL}$ of medium in 200-mL glass jars sealed with Bcaps (Magenta Corp., Chicago). Cultures were incubated under $40 \mu \mathrm{mol} \cdot \mathrm{m}^{-2} \cdot \mathrm{s}^{-1}$ cool-white fluorescent light for $16 \mathrm{~h} /$ day at $24{ }^{\circ} \mathrm{C} \pm 2{ }^{\circ} \mathrm{C}$ with 6-week subcultures. Prior to use in experiments, cultures were subcultured a minimum of six times.

Once rooted, all four cutting types were grown in containers for 2 years and then examined for TP tumors. Tumors were categorized as: 1) absent; 2) small and individual; 3) encompassing one-quarter of the stem; 4) encompassing one-half of the stem; or 5) surrounding the stem. Morphological and growth data were collected as well.

Experimental design and statistical analysis. All experiments were arranged in completely random designs. Analysis of variance was performed on plant growth, shoot, and foliar measurements using the general linear model(GLM) procedure (SAS Institute, 1990). For these variables, within cultivar mean separations between $\mathrm{TP}(-)$ and $\mathrm{TP}(+)$ plants were made using the least significant difference test at $P \leq 0.05$. Tumor incidence and severity data, from plants grown from cuttings of differing ages from micropropagation, were analyzed using multiple Scheffe-Marascuilo comparisons among binomial samples (Marascuilo, 1966).

\section{Results and Discussion}

TP symptom development in plants grown from $T P(+)$ and $T P(-)$ cuttings. The main effects of cultivar and TP status were highly significant at the $P \leq 0.01$ level for all foliar and plant growth characteristics measured. Cultivar $\times$ TP status interactions were significant $(P \leq 0.05)$ for all measured characteristics except the number of leaves per shoot (Table 1).

At least one growth or morphological difference between plants from TP(-) and TP(+) cuttings was evident in all cultivars. The nature and number of characteristics affected and the degree of difference between plants from $\mathrm{TP}(-)$ and $\mathrm{TP}(+)$ cuttings were highly influenced by genotype (Table 1). For example, plants of 'Besse Howells' differed only in the number of leaves per shoot, whereas those of 'Montego' differed in all characteristics measured. In addition, for any given growth or morphological feature, differences were always of the same nature for each cultivar; i.e., if narrower leaves occurred in plants from $\mathrm{TP}(+)$ cuttings of one cultivar, all other cultivars in which this feature was affected had narrower, not wider, leaves.

Leaf size and shape differed between plants from TP( $(-)$ and TP $(+)$ cuttings in three of the seven cultivars in the study (Table 1). Leaf length and leaf width of plants grown from $\mathrm{TP}(+)$ cuttings were either the same as, or less than, those of plants grown from $\mathrm{TP}(-)$ cuttings. 'Montego' exhibited the most pronounced effect, with differences in length and width of 1.6 and $1.3 \mathrm{~cm}$, respectively. As a result of these differences, plants from $\mathrm{TP}(+)$ cuttings of 'Holden', 'Montego', and 'Scintillation' had greater leaf length : width ratios than did plants from TP(-) cuttings. For 'Montego', TP(-) leaves had a length : width ratio of 2.8 , while $\mathrm{TP}(+)$ leaves had a ratio of 3.6 , giving them a very narrow, strap-like appearance. Differences in the size and shape of 'Holden' and 'Scintillation' leaves from plants of TP(+) and TP(-) cuttings were not easily quantified by casual observation. Areas of individual leaves of 'Montego' and 'Scintillation' plants from $\mathrm{TP}(+)$ cuttings were only $58 \%$ and $78 \%$ as large, respectively, as those leaves of plants from TP(-) cuttings.

Shoot growth was affected in three of seven cultivars (Table 1). For 'Boule de Neige', 'Catawbiense Album', and 'Montego', both basal and total shoot length were shorter for plants from $\mathrm{TP}(+)$ cuttings, averaging $62 \%$ and $76 \%$, respectively, of the basal and total shoot length on TP(-) cuttings. All cultivars differed in the number of leaves per shootplants from $\mathrm{TP}(+)$ cuttings producing an average of about one (1.1) more leaf per shoot than plants from TP(-) cuttings.

Reduced canopy size was evident in plants from $\mathrm{TP}(+)$ cuttings of four of the seven cultivars (Table 1). This reduction ranged from $4 \%$ for 'Scintillation' to $43 \%$ for 'Montego'. Tumors were not observed on any plants in this study, regardless of cultivar or TP status of the stock plant.

These data indicate that plants grown from cuttings collected from $\mathrm{TP}(+)$ plants may exhibit shorter, narrower, and smaller leaves than are typical for the cultivar. In addition, they may have shorter shoots, more leaves per shoot, and reduced canopy sizes relative to their $\mathrm{TP}(-)$ counterparts. In an earlier study comparing $\mathrm{TP}(+)$ and $\mathrm{TP}(-)$ plant morphology for Rhododendron 'Montego', Brand and Kiyomoto (1997) found that TP(+) plants with tumors had shorter, narrower, smaller leaves and shorter shoots than TP(-) plants. However, Brand and Kiyomoto (1997) did not observe a difference in number of leaves per shoot between $\mathrm{TP}(+)$ and $\mathrm{TP}(-)$ plants, as was found for all cultivars in this study, including 'Montego'.

Whether plants grown from $\mathrm{TP}(+)$ cuttings 
Table 1. Comparison of shoot and leaf characteristics of seven Rhododendron cultivars, two growing seasons after cutting propagation. Stem cuttings were taken from plants with tissue proliferation tumors $[\mathrm{TP}(+)]$ or without $[\mathrm{TP}(-)]$ tumors or history of micropropagation.

\begin{tabular}{|c|c|c|c|c|c|c|c|c|c|}
\hline \multicolumn{2}{|c|}{ Plant material } & \multicolumn{4}{|c|}{ Avg leaf: } & \multicolumn{2}{|c|}{ Shoot length $(\mathrm{cm})$} & \multirow{2}{*}{$\begin{array}{c}\text { No. leaves } \\
\text { per shoot }\end{array}$} & \multirow{2}{*}{$\begin{array}{l}\text { Plant size } \\
\left(\mathrm{dm}^{3}\right)^{\mathrm{x}}\end{array}$} \\
\hline Cultivar $^{2}$ & TP status & Length $(\mathrm{cm})$ & Width $(\mathrm{cm})$ & Area $\left(\mathrm{cm}^{2}\right)$ & Length/width & Total & Basal $^{y}$ & & \\
\hline \multirow[t]{3}{*}{$\overline{\mathrm{BH}}$} & $\mathrm{TP}(-)$ & $8.5 \mathrm{a}^{\mathrm{w}}$ & 4.0 & $25.9 \mathrm{a}$ & $2.1 \mathrm{a}$ & $9.3 \mathrm{a}$ & $6.5 \mathrm{a}$ & $8.1 \mathrm{~b}$ & $78.0 \mathrm{a}$ \\
\hline & $\mathrm{TP}(+)$ & $8.9 \mathrm{a}$ & $4.2 \mathrm{a}$ & $28.0 \mathrm{a}$ & $2.1 \mathrm{a}$ & $9.9 \mathrm{a}$ & $6.3 \mathrm{a}$ & $8.8 \mathrm{a}$ & $78.3 \mathrm{a}$ \\
\hline & mean & 8.7 & 4.1 & 27.0 & 2.1 & 9.6 & 6.4 & 8.5 & 78.2 \\
\hline \multirow[t]{3}{*}{$\mathrm{BN}$} & $\mathrm{TP}(-)$ & $9.5 \mathrm{a}$ & $3.9 \mathrm{a}$ & $27.8 \mathrm{a}$ & $2.5 \mathrm{a}$ & $12.6 \mathrm{a}$ & $9.4 \mathrm{a}$ & $7.3 \mathrm{~b}$ & $47.5 \mathrm{a}$ \\
\hline & $\mathrm{TP}(+)$ & $9.5 \mathrm{a}$ & $4.1 \mathrm{a}$ & $29.4 \mathrm{a}$ & $2.4 \mathrm{a}$ & $9.6 \mathrm{~b}$ & $6.2 \mathrm{~b}$ & $8.3 \mathrm{a}$ & $37.3 \mathrm{~b}$ \\
\hline & mean & 9.5 & 4.0 & 28.6 & 2.5 & 11.1 & 7.8 & 7.8 & 42.4 \\
\hline \multirow[t]{3}{*}{$\mathrm{CS}$} & $\mathrm{TP}(-)$ & $9.8 \mathrm{a}$ & $3.2 \mathrm{a}$ & $23.0 \mathrm{a}$ & $3.1 \mathrm{a}$ & $11.7 \mathrm{a}$ & $2.7 \mathrm{a}$ & $12.3 \mathrm{~b}$ & $81.2 \mathrm{a}$ \\
\hline & $\mathrm{TP}(+)$ & $9.7 \mathrm{a}$ & $3.1 \mathrm{a}$ & $21.5 \mathrm{a}$ & $3.2 \mathrm{a}$ & $12.2 \mathrm{a}$ & $2.4 \mathrm{a}$ & $13.9 \mathrm{a}$ & $67.4 \mathrm{~b}$ \\
\hline & mean & 9.8 & 3.2 & 22.3 & 3.2 & 12.0 & 2.6 & 13.1 & 74.3 \\
\hline \multirow[t]{3}{*}{$\mathrm{CA}$} & $\mathrm{TP}(-)$ & $8.8 \mathrm{a}$ & $3.8 \mathrm{a}$ & $25.2 \mathrm{a}$ & $2.3 \mathrm{a}$ & $11.8 \mathrm{a}$ & $7.2 \mathrm{a}$ & $9.3 \mathrm{~b}$ & $58.1 \mathrm{a}$ \\
\hline & $\mathrm{TP}(+)$ & $8.6 \mathrm{a}$ & $3.6 \mathrm{a}$ & $25.1 \mathrm{a}$ & $2.4 \mathrm{a}$ & $9.0 \mathrm{~b}$ & $5.3 \mathrm{~b}$ & $10.8 \mathrm{a}$ & $57.6 \mathrm{a}$ \\
\hline & mean & 8.7 & 3.7 & 25.2 & 2.4 & 10.4 & 6.3 & 10.1 & 57.9 \\
\hline \multirow[t]{3}{*}{$\mathrm{HO}$} & $\mathrm{TP}(-)$ & $8.7 \mathrm{a}$ & $3.4 \mathrm{a}$ & $23.5 \mathrm{a}$ & $2.6 \mathrm{~b}$ & $11.1 \mathrm{a}$ & $6.7 \mathrm{a}$ & $10.3 \mathrm{~b}$ & $58.1 \mathrm{a}$ \\
\hline & $\mathrm{TP}(+)$ & $8.6 \mathrm{a}$ & $3.1 \mathrm{~b}$ & $21.1 \mathrm{a}$ & $2.8 \mathrm{a}$ & $9.6 \mathrm{a}$ & $5.7 \mathrm{a}$ & $11.5 \mathrm{a}$ & $57.6 \mathrm{a}$ \\
\hline & mean & 8.7 & 3.3 & 22.3 & 2.7 & 10.4 & 6.2 & 10.9 & 57.9 \\
\hline \multirow[t]{3}{*}{ MO } & $\mathrm{TP}(-)$ & $10.6 \mathrm{a}$ & $3.8 \mathrm{a}$ & $28.4 \mathrm{a}$ & $2.8 \mathrm{~b}$ & $12.1 \mathrm{a}$ & $4.7 \mathrm{a}$ & $14.2 \mathrm{~b}$ & $79.4 \mathrm{a}$ \\
\hline & $\mathrm{TP}(+)$ & $9.0 \mathrm{~b}$ & $2.5 \mathrm{~b}$ & $16.4 \mathrm{~b}$ & $3.6 \mathrm{a}$ & $9.3 \mathrm{~b}$ & $2.2 \mathrm{~b}$ & $15.1 \mathrm{a}$ & $44.9 \mathrm{~b}$ \\
\hline & mean & 9.8 & 3.2 & 22.4 & 3.2 & 10.7 & 3.5 & 14.7 & 62.2 \\
\hline \multirow[t]{3}{*}{$\mathrm{SC}$} & $\mathrm{TP}(-)$ & $10.3 \mathrm{a}$ & $4.6 \mathrm{a}$ & $39.1 \mathrm{a}$ & $2.2 \mathrm{~b}$ & $14.1 \mathrm{a}$ & $9.2 \mathrm{a}$ & $10.2 \mathrm{~b}$ & $44.1 \mathrm{a}$ \\
\hline & $\mathrm{TP}(+)$ & $9.4 \mathrm{~b}$ & $3.9 \mathrm{~b}$ & $30.5 \mathrm{~b}$ & $2.5 \mathrm{a}$ & $13.3 \mathrm{a}$ & $8.7 \mathrm{a}$ & $10.5 \mathrm{a}$ & $42.3 \mathrm{~b}$ \\
\hline & mean & 9.9 & 4.3 & 34.8 & 2.4 & 13.7 & 9.0 & 10.4 & 43.2 \\
\hline \multirow[t]{2}{*}{ mean: } & $\mathrm{TP}(-)$ & 9.5 & 3.8 & 27.6 & 2.5 & 11.8 & 6.6 & 10.2 & 55.5 \\
\hline & $\mathrm{TP}(+)$ & 9.1 & 3.5 & 24.6 & 2.7 & 10.4 & 5.3 & 11.3 & 46.8 \\
\hline \multicolumn{10}{|c|}{$\begin{array}{l}\text { Significance of main effects } \\
\text { and interaction }\end{array}$} \\
\hline \multicolumn{2}{|c|}{ Cultivar } & $* *$ & $* *$ & $* *$ & $* *$ & $* *$ & $* *$ & $* *$ & $* *$ \\
\hline \multicolumn{2}{|c|}{ TP status } & $* *$ & $* *$ & $* *$ & $* *$ & $* *$ & $* *$ & $* *$ & $* *$ \\
\hline \multicolumn{2}{|c|}{ Cultivar $\times$ TP status } & $* *$ & $* *$ & $* *$ & $* *$ & $* *$ & $*$ & NS & $* *$ \\
\hline
\end{tabular}

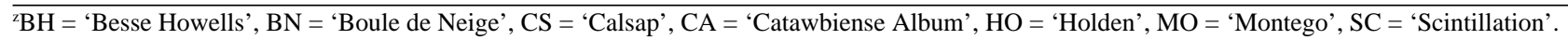

yLength from the bud scale scars to the first leaf on a flush of growth.

xPlant size is the product of two plant widths, taken at right angles to each other, and plant height.

${ }^{\text {w}}$ Mean separation within cultivars by LSD, $P \leq 0.05$.

ss, *, ** Nonsignificant or significant at $P \leq 0.05$ or 0.01 , respectively, by ANOVA.

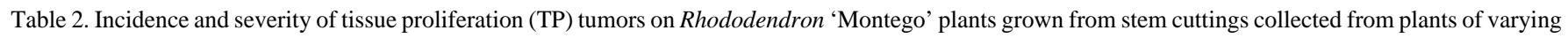
ages postmicropropagation.

\begin{tabular}{|c|c|c|c|c|}
\hline & Microcuttings $^{\mathrm{z}}$ & 3-year-old TP & 6-year-old TP & $\mathrm{TP}(-)^{\mathrm{x}}$ \\
\hline Degree of tumorization & No. plants (\% of total) & $\overline{\text { No. plants (\% of total) }}$ & $\overline{\text { No. plants (\% of total) }}$ & No. plants (\% of total) \\
\hline No tumor & $20(17) b^{w}$ & $10(26) b$ & $42(100) \mathrm{a}$ & $59(100) \mathrm{a}$ \\
\hline Small individual tumors & $13(11) \mathrm{a}$ & $5(13) a b$ & $0(0) b$ & $0(0) \mathrm{b}$ \\
\hline One-quarter of stem surrounded & $23(20) a$ & $9(23) \mathrm{a}$ & $0(0) b$ & $0(0) \mathrm{b}$ \\
\hline One-half of stem surrounded & $26(22) a$ & $11(28) \mathrm{a}$ & $0(0) \mathrm{b}$ & $0(0) \mathrm{b}$ \\
\hline Stem surrounded & $34(29) a$ & $4(10) b$ & $0(0) b$ & $0(0) \mathrm{b}$ \\
\hline Tumor of any size & $97(83) \mathrm{a}$ & $29(74) \mathrm{a}$ & $0(0) b$ & $0(0) \mathrm{b}$ \\
\hline
\end{tabular}

${ }^{2}$ Harvested from in vitro cultures known to produce plants exhibiting TP tumors.

${ }^{y}$ Cuttings were harvested from plants with TP tumors that were 3 and 6 years old, postmicropropagation.

${ }^{x}$ Cuttings were harvested from plants with no TP symptoms and no history of micropropagation.

${ }^{\text {w}}$ Mean separation of percent values within each degree of tumorization using multiple Scheffe-Marascuilo comparisons among binomial samples, $P \leq 0.05$.

develop overt and obvious TP symptoms appears to be highly cultivar-dependent; growers who understand this will be better able to manage or control TP in their production. Clearly, to avoid producing noticeably offtype plants with cultivars such as 'Montego', cuttings should not be collected from $\mathrm{TP}(+)$ stock plants. The absence of tumor development in plants propagated from such plants is encouraging, since tumors are potentially the most problematic TP symptom from both an ornamental and physiological viewpoint. Unfortunately, the absence of tumor development in this study does not prove that plants grown from $\mathrm{TP}(+)$ stock plants will not form tumors under certain conditions. Cultural triggers may exist that stimulate tumor formation (Linderman, 1993; Maynard, 1995), and our growing conditions may not have been conducive to tumor development. However, the lack of tumor formation in plants from $\mathrm{TP}(+)$ cuttings is not surprising, given that cuttings were collected from the distal parts of the plant. The spatial separation of the apical cuttings from the basal region, where TP symptoms are concentrated, could minimize the influence the basal region has on the apical shoots.

Influence of $T P(+)$ plant age from micropropagation on TP symptom development in rooted cuttings. All plants from microcuttings, 3-year-old TP $(+)$ cuttings, and 6-year-old $\mathrm{TP}(+)$ cuttings exhibited small, narrow leaves, shortened shoots, reduced plant canopy size, and an increased number of leaves per shoot when compared with $\mathrm{TP}(-)$ plants (data not shown). Age from micropropagation had no significant effects on plant growth or shoot morphology. However, plants grown from cuttings were more likely to develop tumors when taken from $\mathrm{TP}(+)$ plants that were recently micropropagated (Table 2). When plants were grown from microcuttings, $83 \%$ of them developed tumors, whereas $74 \%$ of those grown from cuttings of 3-year-old $\mathrm{TP}(+)$ plants developed tumors. Additionally, plants from microcuttings exhibited larger tumors than other groups in the study; $51 \%$ developed tumors that surrounded one-half or more of the stem vs. $38 \%$ of plants grown from 3-year-old $\mathrm{TP}(+)$ cuttings and $0 \%$ of plants grown from TP(-) or 6-year-old TP(+) cuttings.

The incidence and severity of TP tumor development in Rhododendron 'Montego' decreased with time after removal from tissue culture, but TP-related shoot growth and morphological differences remained unchanged during the first 6 years. Tumor-forming capacity appeared to be lost in the apical portions of plants sometime between 3 and 6 years after tissue culture. The loss of tumor-forming ca- 
pacity and concurrent retention of altered foliar morphology in Rhododendron 'Montego' in response to increasing time may be analogous to phase change in woody plants such as Hedera helix L. Although tumor-forming capacity in Rhododendron 'Montego' is rapidly lost with time, alterations in shoot morphology may revert to normal appearance more slowly. Both phase change and TP are believed to be epigenetic in nature, providing additional support for a comparison between the two phenomena (Brand and Kiyomoto, 1997; Hartmann et al., 1997).

Although our data with Rhododendron 'Montego' indicate that cuttings collected from sufficiently old micropropagated stock plants will not produce plants with tumors, alterations in foliar morphology will persist in propagated plants. Even though 'Montego' is at the extreme end of the spectrum with regard to TP symptoms, growers should use caution in collecting cuttings from even relatively old micropropagated stock plants, of any cultivar, if the plants have exhibited TP symptoms.

\section{Literature Cited}

Brand, M.H. and R. Kiyomoto. 1992. Abnormal growths on micropropagated elepidote rhododendrons. Comb. Proc. Intl. Plant Prop. Soc. 42:530-534.

Brand, M.H. and R. Kiyomoto. 1994. Tissue proliferation apparently not lignotubers. Yankee Nursery Quart. 3:5-6.

Brand, M.H. and R. Kiyomoto. 1997. The induction of tissue proliferation-like characteristics in in vitro cultures of Rhododendron 'Montego'. HortScience 32:989-994.

Del Tredici, P. 1992. Seedling vs. tissue-cultured Kalmia latifolia: The case of the missing burl. Comb. Proc. Intl. Plant Prop. Soc. 42: 476-482.

Hartmann, H.T., D.E. Kester, F.T. Davies, Jr., and R.L. Geneve. 1997. Plant propagation. Prentice Hall, Upper Saddle River, N.J.

La Mondia, J.L., T.M. Rathier, V.L. Smith, T.M. Likens, and M.H. Brand. 1992. Tissue proliferation/crown gall in rhododendron. Yankee Nursery Quart. 2:1-3.

Linderman, R.G. 1993. Tissue proliferation. Amer. Nurseryman 178(5):57-67.

Lloyd, G. and B. McCown. 1980. Commerciallyfeasible micropropagation of mountain laurel,
Kalmia latifolia, by use of shoot tip culture. Comb. Proc. Intl. Plant Prop. Soc. 30:421-426.

Marascuilo, L.A. 1966. Large-sample multiple comparisons. Psychol. Bul. 65:280-290.

Maynard, B.K. 1995. Research update on tissue proliferation. Comb. Proc. Intl. Plant Prop. Soc. 45:442-447.

McCulloch, S.M. and J.M. Britt. 1997. Industry experiences and research with tissue proliferation. HortScience 32:986-989.

Mercure, E.W., C.S. Jones, M.H. Brand, and C.A. Auer. 1998. Anatomy of shoots and tumors of in vitro habituated Rhododendron 'Montego' (Ericaceae) cultures with tissue proliferation. Amer. J. Bot. 85:616-628.

Mudge, K.W., J.P. Lardner, H.K. Mahoney, and G.L. Good. 1997. Field evaluation of tissue proliferation of rhododendron. HortScience 32:995-998.

SAS Institute. 1990. SAS/STAT user's guide, vers. $6,4^{\text {th }}$ ed. SAS Inst., Cary, N.C.

Zimmerman, R.H. 1997. A review of tissue proliferation in rhododendron, p. 355-362. In: A.C. Cassells (ed.). Pathogen and microbial contamination in micropropagation. Kluwer Academic, The Netherlands. 